\title{
COMPARATIVE EVALUATION OF THREE PROMISING STRAINS AND EGYPTIAN COTTON EXTRA LONG STAPLE COMMERCIAL CULTIVARS GROWN AT DIFFERENT LOCATIONS
}

\author{
HASSAN, I.S.M, H. A. IDRIS AND S.S.M. BADR \\ Cotton Research Institute, ARC, Giza, Egypt.
}

(Manuscript received 4 April 2012)

\begin{abstract}
Three promising strains Extra long staple cotton genotypes were evaluated compared with the four commercial cultivars grown in five different locations in Lower Egypt during the two successive seasons 2009 and 2010. Randomized complete block design with four replications was used at each location. The traits studied were seed cotton yield, lint yield, boll weight, lint percentage, seed index, lint index, fiber length, fiber strength and micronaire reading. Highly significant differences between genotypes, locations, seasons and the interaction between locations by seasons were obtained for yield, yield components and fiber quality properties. The effect of the interaction between genotypes by locations was highly significant for all traits except, seed index and lint index, but the interaction between genotypes by seasons and the second interaction were significant for all traits except, seed index.

The results showed that the two promising strains [G.84 (G. 70 $\times$ G. 51 b) $] \times$ Pima 62 and G.88 $(G .68 \times$ G.45) produced the highest values for yield and most yield components traits than the other cultivars. However the promising strain $(\mathrm{G} .77 \times \mathrm{S} 6)$ had the highest fiber length and fineness. From the results, the promising strain (Giza $77 \times \mathrm{S} 6$ ) exceeded the commercial cultivar Giza 87 in fineness at three locations (Kafr El-Sheikh, El-Dakahlia and Damiatta) regions. Adaptation to different environments was high in the promising strain (Giza $77 \times 56$ ) at El-Beheira region for most characters. The promising strains [G.84 (G.70 X G 51b)] × Pima 62 and G.88 (G.68 × G.45) produced the highest values than the commercial cultivars Giza 70 and Giza 88 for yield, most yield components and fiber properties at El-Dakahlia region. Therefore, it seems necessary to continue evaluating new cotton genotypes by growing them at several locations over an adequate number of years before recommending any variety for a certain location.
\end{abstract}

\section{INTRODUCTION}

Cotton is one of the most important fiber crops in the world and is likely to enjoy this advantage in the future. In Egypt, cotton is important for both export and local textile industry. Cotton area of cultivation extends longitudinally about $1000 \mathrm{Km}$ from northern to southern of Egypt. Because environmental conditions vary or likely 
to vary from one location to another and / or from year to year in this extended area, the evaluation process of the commercial varieties as well as the newly released or promising strains over different locations and over different years is of great importance to the breeder. It is essential to develop new varieties characterized by high yielding abilities and better fiber qualities to replace old ones or those which had deteriorated.

Therefore, the Regional Evaluation Research Section, C. R. I., carries out yearly regional variety tests in all cotton locations with the main objective of identifying the best locations for the new varieties and the best degeneration or deterioration of the latter. Several workers studied the performance of cotton varieties under different environments (Abo El-Zahab et al., 1992; Abou-Tour et al., 1996; Badr and El Sayed 2004 and Hassan et al., 2005); they reported that the effects of genotypes, location, years and the interactions between them were significant for some cotton traits. Many investigators studied the improved cotton yield and quality traits. Abdel Salam et. al. (1985) found that the combined analysis of variance indicated that most of the variation in the quality properties studied was due to varieties effects and followed in descending order by the varieties $\times$ years and varieties $\times$ subregions interactions. Badr (1994) reported that the interaction between genotypes and locations were significant for seed cotton yield, lint yield, boll weight, lint percentage, seed index, micronaire reading and yarn strength. Hanuman and Singh (1994) reported that the effect of genotype, location, years and interactions between them were significant for seed index, ginning out-turn and hallo length. Seyam and Abd ElRahman (1994) showed that genotypes $x$ locations interactions were significant for seed and lint cotton yield / plot, boll weight, lint percentage, seed index and micronaire reading. Abou - Tour et. al. (1996) reported that the effect of genotype, location, year and the interactions between them were significant for seed cotton yield, boll weight, seed index, micronaire reading and yarn strength. Hassan (2000) reported that the first order interaction of genotypes $x$ years was statistically significant for all characters except seed index, micronaire reading and $2.5 \%$ span length. The genotypes $\times$ locations interactions were highly significant for all traits except yarn strength. The second order interaction (genotype $\times$ location $\times$ year) was highly significant for lint yield, boll weight and micronaire reading. Badr (2003) reported that all traits showed highly significant mean squares for environments and genotype $\times$ environment interaction. Hassan et. al. (2005) showed that the effect of genotypes, years, locations, (genotype $\times$ location) and the second order interaction were highly significant for seed cotton yield and seed index. While the first order 
interaction (genotype $\times$ year) was insignificant for seed index. Hassan et. al. (2006) showed that the effect of genotypes, years, locations, and the interactions between them were highly significant for most yield and yield components. While the first order interaction (genotype $\times$ year) and (genotype $\times$ location) were significant for $2.5 \%$ span length. But the second order interaction was insignificant for all fiber properties. Hassan (2006) found that the studied genotypes, locations and years varied significantly in all studied traits. Also, the effect of (locations $\times$ years), (genotype $\times$ location) were highly significant for all traits except boll weight, lint percentage and seed index, while the effect of (genotype $\times$ year) interaction was significant for all characters except, lint percentage and seed index. Arafa et. al. (2008) noticed that the highest $\mathrm{DD}_{15} \mathrm{DD}_{15}$ 's exhibited the highest values of boll weight ( $\mathrm{gm}$ ), lint \%, seed index, seed cotton yield (K/F) and lint cotton yield (K/F) for all cultivars except, Giza 87 cultivar which was adapted to a wide range of accumulated heat units. The highest values of earliness \% were $(88.55,95.15,96.17,94.96,90.88$ and 98.16) for G. 45, G.87, G.70, G.85, G. 86 and G.89 respectively at the highest $D^{15}{ }_{15}$ 's. While the highest value of earliness \% was (96.84 and 91.43) for the two lowest $D_{15}{ }_{15}^{\prime}$ s for Giza 88 cultivar only. El-Feky and Hassan (2011) showed that no significant differences in fiber properties were due to growing G.86 and G.85 for some locations. This could be attributed to the growing locations had the same environmental conditions.

The main objective of the present study was to determine the effect of genotypes, locations, years and their interactions on yield, some yield components, fiber and open - end yarn properties in the same cotton genotypes.

\section{MATERIALS AND METHODS}

This study included four Egyptian cotton cultivars, Giza 70, Giza 87, Giza 88 and Giza 92 and three new promising strains (G.77 × S6), [G.84 (G. $70 \times$ G. 51 b)] $\times$ Pima 62 and G.88 (G.68 × G.45) were grown in two successive seasons, i.e.2009 and 2010 at five locations of lower Egypt i.e., El-Gharbia (Mahalt Kasab), Kafr ElSheikh (Sedi Salim), El-Dakahlia (Dekernise), Damiatta (Kafr Saad) and El-Beheira (Abou Homies). Data of yield and yield components of the studied genotypes were obtained from the yield miniature experiments conducted by Regional Evaluation Research Department of the Cotton Research Institute. The experimental design was a randomized complete block with four replications at each location. The sowing dates were from April - 10 to April - 20 for the two seasons. The plot size was $62.4 \mathrm{~m}^{2}$ containing 12 ridges of eight meters long and $65 \mathrm{~cm}$ wide. Distance between hills was $25 \mathrm{~cm}$ apart and each hill was thinned to two plants per hill after six weeks. The first 
irrigation was given three weeks after sowing, and the second was three weeks later. Culture practices were carried out as recommended in cotton fields. Data were collected for the following traits:

- Seed cotton yield $(\mathrm{k} / \mathrm{f})$ : obtained as weight of seed cotton yield per plot and converted to kentar per feddan (kentar $=157.5 \mathrm{k} . \mathrm{g}$ ).

- Lint cotton yield: calculated as follows: (weight of seed cotton yield per feddan $\times$ lint percentage).

A random sample of 50 bolls was harvested at random from each plot and was used to obtain plot mean values for:

a- Boll weight in grams: the average weight in grams of 50 bolls.

b- Lint percentage (L.P): ratio of lint weight to seed cotton weight in the sample expressed as percentage.

c- Seed index (S.I): weight of 100 seeds in grams.

d- Lint index: the weight of lint produced by 100 seeds in grams:

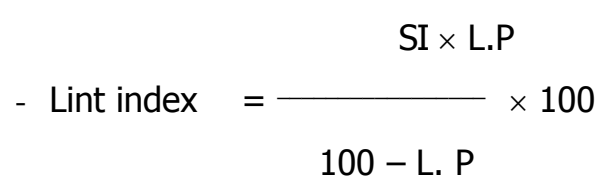

Samples of lint cotton from each genotype under each location were analyzed in the laboratories of the Cotton Technology Research Division at Giza, Cotton Research Institute to determine fiber qualities, under controlled conditions of $65 \pm 2 \%$ of relative humidity and $70 \pm 2 \mathrm{~F}^{\circ}$ temperature for all samples. Fiber properties were measured by using High Volume Instrument (HVI) according to (A.S.T.M. D-46051986) for fiber properties:

a- Fiber length (upper half mean $\mathrm{mm}$ ).

b- Micronaire reading.

c- Fiber strength ( $\mathrm{g} / \mathrm{tex}$ )

\section{Statistical analysis:}

Analysis of variance was done according to Snedecor and Cochran (1982) for each location. Combined analysis for all regions was performed on all the studied traits as outlined by Micntosh (1983). Differences between means were compared by using the Least Significant Differences (L.S.D.) 


\section{RESULTS AND DISCUSSION}

The results reported in this investigation included the evaluation of three promising strains and four Egyptian cotton cultivars in the two seasons, i.e.2009 and 2010 at five different locations of Lower Egypt in order to study the effects of genotypes, locations, years and their interactions.

The combined analysis of the genotypes, locations, years and the interactions between them are shown in Table (1). The results of the combined analysis of variance showed that the effect of genotypes, locations and years were highly significant for all studied traits. Also, the effect of the first order interaction (location by year) was highly significant for all studied characters. However, the first order interaction (genotypes $\mathrm{x}$ locations) was highly significant for all studied traits except, seed index and lint index.

Table 1. Mean squares for all characters for seven Egyptian cotton genotypes grown at five locations over two years (2009 and 2010).

\begin{tabular}{|c|c|c|c|c|c|c|c|c|}
\hline \multirow[t]{2}{*}{ Characters } & S.O.V & $\begin{array}{c}\text { Genotypes } \\
\text { (G) }\end{array}$ & $\begin{array}{l}\text { Locations } \\
\text { (L) }\end{array}$ & $\begin{array}{c}\text { Years } \\
(Y) \\
\end{array}$ & $L \times Y$ & $G \times L$ & $\mathrm{G} \times \mathrm{Y}$ & $G \times L \times Y$ \\
\hline & d.f & 6 & 4 & 1 & 4 & 24 & 6 & 24 \\
\hline \multicolumn{2}{|c|}{ Seed cotton yield (k/f) } & $27.60 * *$ & $20.05 * *$ & $15.50 * *$ & $81.58^{* *}$ & $1.549 * *$ & $2.569 * *$ & 1.110* \\
\hline \multicolumn{2}{|c|}{ Lint cotton yield $(k / f)$} & $63.17 * *$ & $32.54 * *$ & $16.48^{* *}$ & $92.54 * *$ & $2.231 * *$ & $3.724 * *$ & 1.634* \\
\hline \multicolumn{2}{|c|}{ Boll weight $(\mathrm{g})$} & $1.034 * *$ & $1.643 * *$ & $0.537 * *$ & $3.507 * *$ & $0.065^{* *}$ & $0.079 * *$ & $0.050 * *$ \\
\hline \multicolumn{2}{|c|}{ Lint percentage } & $130.8^{* *}$ & $14.41 * *$ & $4.654 * *$ & $21.85^{* *}$ & $1.573 * *$ & $3.102 * *$ & $1.491^{* *}$ \\
\hline \multicolumn{2}{|c|}{ Seed index $(g)$} & $3.373 * *$ & $18.23 * *$ & $10.49 * *$ & $34.46 * *$ & 0.375 & 0.711 & 0.365 \\
\hline \multicolumn{2}{|l|}{ Lint index (g) } & $10.99 * *$ & $9.049 * *$ & $1.572 * *$ & $8.362^{* *}$ & 0.205 & $0.483 * *$ & $0.254 *$ \\
\hline \multicolumn{2}{|c|}{ Upper half mean (mm) } & $37.47 * *$ & $19.44 * *$ & $26.17 * *$ & $11.13^{* *}$ & $2.806 * *$ & $2.749 * *$ & $2.025 * *$ \\
\hline \multicolumn{2}{|c|}{ Fiber strength (g/tex) } & $73.74 * *$ & $27.65^{* *}$ & $1.744 * *$ & $9.143 * *$ & $26.47 * *$ & $24.78 * *$ & $13.77 * *$ \\
\hline \multicolumn{2}{|c|}{ Micronaire reading } & $3.495^{* *}$ & $2.607 * *$ & $1.008^{* *}$ & $1.302^{* *}$ & $0.143 * *$ & $0.360 * *$ & $0.088 * *$ \\
\hline
\end{tabular}

$*, * *$ Significant at the 0.05 and 0.01 probability levels, respectively.

The first order interaction (genotypes $x$ years) and the second order interaction were significant for all studied traits except, seed index.

The results suggest that comparisons among these cotton genotypes for the studied traits should be independently estimated at each sub region over several years. These results confirm the findings of Abo-Tour et. al. (1996), Badr and El Sayed (2004), Hassan et. al. (2005) and Hassan (2006), who reported that genotypes, locations, years and the interactions between them were significant for some yield components. 


\section{Cotton varietals differential:}

Data in Table (2). Showed the effect of different cotton genotypes on studied yield and quality traits. These genotypes under study were significantly different with regard to these studied traits. The two promising strains [G.84 (G.70 X G 51b)] $\times$ Pima 62 and G.88 (G.68 × G.45) produced the highest seed cotton yield (k/f), lint cotton yield $(\mathrm{K} / \mathrm{F})$, boll weight $(\mathrm{g})$ and lint index $(\mathrm{g})$ than all other genotypes.

With respect to fiber properties, it can be noticed that the promising strain $(\mathrm{G} .77 \times \mathrm{S} 6)$ had the highest values for fiber length and fineness (micronaire reading) than all the other genotypes.

Table 2. Effect of different cotton genotypes on yield, yield components and fiber quality over two years and five locations.

\begin{tabular}{|c|c|c|c|c|c|c|c|c|}
\hline Characters & G. 70 & G. 87 & G. 88 & G. 92 & $\begin{array}{c}(\mathrm{G} .77 \times \\
\mathrm{S} 6)\end{array}$ & $\begin{array}{c}\text { [G.84 } \\
\text { (G.70 X } \\
\text { G 51b)] } \\
\times \text { Pima } \\
62 \\
\end{array}$ & $\begin{array}{c}\text { G.88 } \\
(G .68 \times \\
\text { G.45) }\end{array}$ & $\begin{array}{l}\text { LSD } \\
0.05\end{array}$ \\
\hline Seed cotton yield $(\mathrm{k} / \mathrm{f})$ & 7.06 & 7.74 & 7.64 & 8.75 & 7.19 & 8.99 & 8.94 & 0.33 \\
\hline Lint cotton yield $(\mathrm{k} / \mathrm{f})$ & 8.40 & 8.23 & 9.06 & 10.14 & 8.03 & 11.18 & 10.58 & 0.41 \\
\hline Boll weight (g) & 2.55 & 2.37 & 2.61 & 2.64 & 2.38 & 2.78 & 2.75 & 0.07 \\
\hline Lint percentage & 37.85 & 33.87 & 37.66 & 36.82 & 35.54 & 39.49 & 37.56 & 0.38 \\
\hline Seed index $(\mathrm{g})$ & 8.92 & 9.02 & 9.40 & 9.47 & 9.09 & 9.47 & 9.71 & 0.28 \\
\hline Lint index $(\mathrm{g})$ & 5.43 & 4.62 & 5.68 & 5.52 & 5.00 & 6.19 & 5.85 & 0.16 \\
\hline Upper half mean $(\mathrm{mm})$ & 34.48 & 35.05 & 35.42 & 33.18 & 36.34 & 35.30 & 35.06 & 0.03 \\
\hline Fiber strength (g/tex) & 44.52 & 44.77 & 48.40 & 46.78 & 46.24 & 45.51 & 45.16 & 0.03 \\
\hline Micronaire reading & 3.60 & 3.12 & 3.54 & 3.47 & 2.84 & 3.65 & 3.46 & 0.02 \\
\hline
\end{tabular}

The new variety $\mathrm{G} .87$ produced higher seed cotton yield $\mathrm{k} / \mathrm{f}$ than the promising strain $(\mathrm{G} .77 \times \mathrm{S} 6)$, but the differences between them was non significant for lint cotton yield k/f. The promising strain [G.84 (G.70 X G 51b)] $\times$ Pima 62 produced significantly higher seed cotton yield k/f and lint cotton yield k/f than $\mathrm{G} .70$ by $1.93 \mathrm{k} / \mathrm{f}$ $(27.3 \%)$ and $2.78 \mathrm{k} / \mathrm{f}(33.1 \%)$, respectively. In addition, it produced significant higher boll weight, lint percentage, seed index and lint index than G.70. Comparing the promising strain [G.84 (G.70 X G 51b)] $\times$ Pima 62 as a potential substitute for

G.70, it could be observed from Table (2) this promising strain exceeded significantly $\mathrm{G} .70$ in fiber length and fiber strength $(\mathrm{g} / \mathrm{tex})$.

Comparing the promising strain G.88 $(\mathrm{G} .68 \times \mathrm{G} .45)$ as a potential substitute for G.88, it could be observed from Table (2) this promising strain exceeded significantly G.88 in seed cotton yield and lint cotton yield k/f by $1.303 \mathrm{k} / \mathrm{f}(17 \%)$ and $1.52 \mathrm{k} / \mathrm{f}$ $(16.8 \%)$, respectively. However, G.88 exceeded significantly the promising strain G.88 (G.68 × G.45) in fiber length and fiber strength ( $\mathrm{g} / \mathrm{tex})$. These results are in 
agreement with those obtained by Abo El-Zahab et. al. (1992), Badr (2003), Hassan et. al. (2005), Hassan (2006) and El-Feky and Hassan (2011).

\section{Effect of locations on the studied traits:}

Table (3) shows the average values of studied traits as affected by different locations. The data indicated that the average values of seed cotton yield $\mathrm{k} / \mathrm{f}$ and lint cotton yield $\mathrm{k} / \mathrm{f}$ were significantly different where the highest values were obtained from genotypes grown at El-Dakahlia region. El-Gharbia and El-Dakahlia regions produced the highest values of lint index, but the lowest was reported at Damiatta.

Table 3. Average of studied traits as affected by different growing locations.

\begin{tabular}{|l|c|c|c|c|c|c|}
\hline \multicolumn{1}{|c|}{ Characters } & El-Gharbia & $\begin{array}{c}\text { Kafr El- } \\
\text { Sheikh }\end{array}$ & El-Dakahlia & Damiatta & El-Beheira & LSD 0.05 \\
\hline Seed cotton yield (k/f) & 8.19 & 7.29 & 8.90 & 7.72 & 8.13 & 0.28 \\
\hline Lint cotton yield (k/f) & 9.68 & 8.56 & 10.50 & 8.83 & 9.31 & 0.35 \\
\hline Boll weight (g) & 2.68 & 2.58 & 2.70 & 2.29 & 2.66 & 0.06 \\
\hline Lint percentage & 37.42 & 37.14 & 37.42 & 36.32 & 36.56 & 0.32 \\
\hline Seed index (g) & 9.63 & 9.06 & 9.62 & 8.40 & 9.78 & 0.23 \\
\hline Lint index (g) & 5.78 & 5.36 & 5.76 & 4.82 & 5.63 & 0.14 \\
\hline Upper half mean (mm) & 35.65 & 34.65 & 35.55 & 34.32 & 34.70 & 0.03 \\
\hline Fiber strength (g/tex) & 46.48 & 45.81 & 46.50 & 45.98 & 44.78 & 0.03 \\
\hline Micronaire reading & 3.54 & 3.38 & 3.49 & 3.01 & 3.49 & 0.02 \\
\hline
\end{tabular}

With respect to the fiber properties, the highest fiber length produced at ElGharbia region, surpassed significantly the other locations. El-Dakahlia region recorded higher reading for fiber strength ( $\mathrm{g} / \mathrm{tex}$ ), but El-Beheira produced the lowest value for this trait. While Damiatta region produced the best fineness from the other locations. These results were in agreement with those obtained by Abo El-Zahab et. al. (1992), Abou-Tour et. al. (1996), Badr (2003), Badr and El-Sayed (2004), Hassan (2006) and El-Feky and Hassan (2011).

\section{Effect of seasons on cotton yield, yield components and lint quality:}

Table (1) and (4) showed that the values of cotton yield and some related traits as well as lint quality properties were affected by the growing season. Table (1) showed that all characters were highly significant. The data in Table (4) indicated that seed cotton yield, lint cotton yield, boll weight, seed index, lint index, fiber length and fiber strength ( $g /$ tex) recorded the highest values during the second season (2010) and the differences between it and the other season were significant for these traits. While, lint percentage gave the highest value during the first season (2009). 
Table 4. Average of studied traits as affected by different growing seasons.

\begin{tabular}{|l|c|c|c|}
\hline \multirow{2}{*}{\multicolumn{1}{|c|}{ Characters }} & \multicolumn{2}{c|}{ Seasons } & \multirow{2}{*}{ LSD 0.05 } \\
\cline { 2 - 3 } & 2009 & 2010 & 0.18 \\
\hline Seed cotton yield $(\mathrm{k} / \mathrm{f})$ & 7.81 & 8.28 & 0.22 \\
\hline Lint cotton yield $(\mathrm{k} / \mathrm{f})$ & 9.13 & 9.62 & 0.04 \\
\hline Boll weight $(\mathrm{g})$ & 2.54 & 2.63 & 0.20 \\
\hline Lint percentage & 37.10 & 36.84 & 0.15 \\
\hline Seed index $(\mathrm{g})$ & 9.10 & 9.49 & 0.09 \\
\hline Lint index $(\mathrm{g})$ & 5.40 & 5.54 & 0.02 \\
\hline Upper half mean (mm) & 34.67 & 35.28 & 0.02 \\
\hline Fiber strength $(\mathrm{g} /$ tex $)$ & 45.83 & 45.99 & 0.01 \\
\hline Micronaire reading & 3.32 & 3.44 & \\
\hline
\end{tabular}

The cotton genotypes grown in the first season gave the best fineness. This may be due to the variation in climatic conditions from year to year. These results were in harmony with those obtained by Abo El-Zahab et. al. (1992), Abou-Tour et. al. (1996), Badr (2003), Badr and El-Sayed (2004), Hassan et. al. (2006) and El-Feky and Hassan (2011). They reported that the effect of location had a significant for these characters.

Effect of the interaction between growing locations and growing seasons on cotton yield, yield components and lint quality

With respect to the locations $\times$ seasons interaction, it can be seen from Table (5) that this interaction was significantly on all traits. The highest seed cotton yield of $(10.02 \mathrm{k} / \mathrm{f})$, lint cotton yield $(11.21 \mathrm{k} / \mathrm{f})$, boll weight $(3.03 \mathrm{~g})$ and seed index (10.90 g) were obtained from cotton genotypes grown at El-Beheira region during the second season. The highest value of lint percentage (37.79\%) was obtained from cotton genotypes at El-Beheira region during the first season, but El-Dakahlia region during the first season gave the highest value of lint index $(6.01 \mathrm{~g})$.

With respect to the upper half mean (fiber length) and fiber strength $(\mathrm{g} / \mathrm{tex})$, it could be observed that the highest values were obtained from cotton genotypes at ElGharbia region during the second season $(36.06 \mathrm{~mm})$ and $(47.05)$, respectively. The best fineness (micronaire reading) was obtained from cotton genotypes at Damiatta during the first season. 
Table 5. Effect of the interaction between growing locations and growing seasons on the studied traits.

\begin{tabular}{|c|c|c|c|c|c|c|c|}
\hline Characters & Season & $\begin{array}{c}\text { El- } \\
\text { Gharbia }\end{array}$ & $\begin{array}{l}\text { Kafr El- } \\
\text { Sheikh }\end{array}$ & $\begin{array}{c}\text { El- } \\
\text { Dakahlia }\end{array}$ & Damiatta & $\begin{array}{c}\text { El- } \\
\text { Beheira }\end{array}$ & $\begin{array}{l}\text { LSD } \\
0.05\end{array}$ \\
\hline $\begin{array}{l}\text { Seed cotton yield } \\
\qquad(\mathrm{k} / \mathrm{f})\end{array}$ & $\begin{array}{l}2009 \\
2010\end{array}$ & $\begin{array}{l}7.30 \\
9.08\end{array}$ & $\begin{array}{l}7.55 \\
7.03\end{array}$ & $\begin{array}{l}10.18 \\
7.61\end{array}$ & $\begin{array}{l}7.79 \\
7.64\end{array}$ & $\begin{array}{r}6.23 \\
10.02\end{array}$ & 0.40 \\
\hline $\begin{array}{l}\text { Lint cotton yield } \\
\qquad(\mathrm{k} / \mathrm{f})\end{array}$ & $\begin{array}{l}2009 \\
2010\end{array}$ & $\begin{array}{r}8.61 \\
10.75\end{array}$ & $\begin{array}{l}8.85 \\
8.26\end{array}$ & $\begin{array}{l}11.94 \\
9.06\end{array}$ & $\begin{array}{l}8.85 \\
8.82\end{array}$ & $\begin{array}{r}7.41 \\
11.21\end{array}$ & 0.49 \\
\hline Boll weight (g) & $\begin{array}{l}2009 \\
2010\end{array}$ & $\begin{array}{l}2.80 \\
2.56\end{array}$ & $\begin{array}{l}2.68 \\
2.49\end{array}$ & $\begin{array}{l}2.89 \\
2.50\end{array}$ & $\begin{array}{l}2.03 \\
2.55\end{array}$ & $\begin{array}{l}2.30 \\
3.03\end{array}$ & 0.08 \\
\hline Lint percentage & $\begin{array}{l}2009 \\
2010\end{array}$ & $\begin{array}{l}37.36 \\
37.49\end{array}$ & $\begin{array}{l}37.12 \\
37.16\end{array}$ & $\begin{array}{l}37.17 \\
37.66\end{array}$ & $\begin{array}{l}36.06 \\
36.57\end{array}$ & $\begin{array}{l}37.79 \\
35.33\end{array}$ & 0.45 \\
\hline Seed index (g) & $\begin{array}{l}2009 \\
2010\end{array}$ & $\begin{array}{l}9.87 \\
9.40\end{array}$ & $\begin{array}{l}9.43 \\
8.69\end{array}$ & $\begin{array}{l}10.13 \\
9.10\end{array}$ & $\begin{array}{l}7.44 \\
9.37\end{array}$ & $\begin{array}{r}8.65 \\
10.90\end{array}$ & 0.33 \\
\hline Lint index (g) & $\begin{array}{l}2009 \\
2010\end{array}$ & $\begin{array}{l}5.91 \\
5.65\end{array}$ & $\begin{array}{l}5.58 \\
5.14\end{array}$ & $\begin{array}{l}6.01 \\
5.51\end{array}$ & $\begin{array}{l}4.21 \\
5.42\end{array}$ & $\begin{array}{l}5.26 \\
5.99\end{array}$ & 0.19 \\
\hline $\begin{array}{l}\text { Upper half mean } \\
\qquad(\mathrm{mm})\end{array}$ & $\begin{array}{l}2009 \\
2010\end{array}$ & $\begin{array}{l}35.24 \\
36.06\end{array}$ & $\begin{array}{l}34.94 \\
34.35\end{array}$ & $\begin{array}{l}35.45 \\
35.65\end{array}$ & $\begin{array}{l}33.41 \\
35.24\end{array}$ & $\begin{array}{l}34.30 \\
35.11\end{array}$ & 0.04 \\
\hline $\begin{array}{l}\text { Fiber strength } \\
\qquad(g / \text { tex })\end{array}$ & $\begin{array}{l}2009 \\
2010\end{array}$ & $\begin{array}{l}45.91 \\
47.05\end{array}$ & $\begin{array}{l}46.26 \\
45.36\end{array}$ & $\begin{array}{l}46.59 \\
46.42\end{array}$ & $\begin{array}{l}45.59 \\
46.37\end{array}$ & $\begin{array}{l}44.81 \\
44.74\end{array}$ & 0.04 \\
\hline Micronaire reading & $\begin{array}{l}2009 \\
2010\end{array}$ & $\begin{array}{l}3.53 \\
3.54\end{array}$ & $\begin{array}{l}3.40 \\
3.36\end{array}$ & $\begin{array}{l}3.60 \\
3.38\end{array}$ & $\begin{array}{l}2.85 \\
3.16\end{array}$ & $\begin{array}{l}3.22 \\
3.76\end{array}$ & 0.03 \\
\hline
\end{tabular}

Therefore, it could be concluded that the mean values of different traits varied from location to another according to the year of production. These results corresponded with the finding of Badr (1994), Abou-Tour et. al. (1996), Hassan (2000), Hassan et. al. (2006), Arafa et. al. (2008) and El-Feky and Hassan (2011), who reported that the interaction between locations and seasons were significantly different on some yield components and fiber properties. 


\section{Effect of the interaction between cotton genotypes and growing locations on cotton yield, yield components and lint quality}

Table (6) showed that the genotypes $\times$ Locations interaction was significant for all traits except, seed index and lint index traits.

Comparing the promising strain (Giza $77 \times \mathrm{S} 6$ ) as an expected substitution for the commercial cultivar Giza 87, it can be seen that this promising strain produced the highest values for seed cotton yield $(k / f)$, lint cotton yield $(k / f)$, boll weight $(g)$, lint percentage and fiber strength $(\mathrm{g} /$ tex) at El-Beheira region, the differences between them were significant for these traits.

The promising strain (Giza $77 \times$ S6) exceeded the commercial cultivar Giza 87 in fineness at three locations (Kafr El-Sheikh, El-Dakahlia and Damiatta) regions. Adaptation to different environments were high in the promising strain (Giza $77 \times$ S6) at El-Beheira region for most traits, hence, this promising strain may be recommended to be grown at El-Beheira.

Comparing the promising strains [G.84 (G.70 X G 51b)] × Pima 62 and G.88 (G.68 $\times$ G.45) as an expected substitution for the commercial cultivars Giza 70 and Giza 88, it could be noticed that the two promising strains produced the highest values for most yield, yield components and fiber properties at El-Dakahlia region. These promising strains may be recommended to be grown at El-Dakahlia governorate.

These results generally were corresponded with the findings of Abo El-Zahab et. al. (1992), Badr (1994), Abou-Tour et. al. (1996), Badr and El-Sayed (2004), Hassan et. al. (2005) and Arafa et. al. (2008) who reported that the effect of genotypes $\times$ locations interaction was significant for some yield, yield component and fiber properties.

Effect of the interaction between cotton genotypes and growing seasons on cotton yield, yield components and lint quality

Table (7) showed the average of the studied cotton traits for the seven Egyptian cotton genotypes grown during the two successive seasons (2009 and 2010). Only one trait showed insignificant effect (seed index), while all the other traits were significant.

Seed cotton yield $(\mathrm{k} / \mathrm{f})$ ranged from $6.67 \mathrm{k} / \mathrm{f}$ for the promising strain (Giza $77 \times$ S6) during the first season to $9.12 \mathrm{k} / \mathrm{f}$ for the promising strain G.88 (G.68 $\times$ G.45) during the second season. Also, lint cotton yield k/f ranged from $7.47 \mathrm{k} / \mathrm{f}$ for the promising strain (Giza $77 \times \mathrm{S} 6$ ) during the first season to $11.31 \mathrm{k} / \mathrm{f}$ for the promising strain [G.84 (G.70 X G 51b)] × Pima S62 during the first season. 
Table 6. Effect of the interaction between genotypes and growing locations on the studied traits.

\begin{tabular}{|c|c|c|c|c|c|c|c|}
\hline Characters & Genotypes & $\begin{array}{c}\text { El- } \\
\text { Gharbia }\end{array}$ & $\begin{array}{l}\text { Kafr El- } \\
\text { Sheikh }\end{array}$ & $\begin{array}{c}\text { El- } \\
\text { Dakahlia }\end{array}$ & Damiatta & $\begin{array}{c}\text { El- } \\
\text { Beheira }\end{array}$ & $\begin{array}{l}\text { LSD } \\
0.05\end{array}$ \\
\hline $\begin{array}{l}\text { Seed cotton } \\
\text { yield }(k / f)\end{array}$ & $\begin{array}{c}\text { Giza 70 } \\
\text { Giza 87 } \\
\text { Giza 88 } \\
\text { Giza 92 } \\
(\text { G.77 × S6) } \\
\text { [G.84 (G.70 X G 51b)] × Pima } 62 \\
\text { G.88 }(\text { G.68 } \times \text { G.45) }\end{array}$ & $\begin{array}{l}8.00 \\
7.80 \\
8.23 \\
8.57 \\
7.36 \\
8.44 \\
8.95\end{array}$ & $\begin{array}{l}5.98 \\
6.94 \\
7.09 \\
8.35 \\
6.38 \\
8.24 \\
8.06\end{array}$ & $\begin{array}{c}8.01 \\
8.86 \\
8.16 \\
9.56 \\
7.41 \\
10.34 \\
9.94\end{array}$ & $\begin{array}{l}6.36 \\
7.88 \\
7.18 \\
8.40 \\
6.56 \\
8.98 \\
8.66\end{array}$ & $\begin{array}{l}6.95 \\
7.19 \\
7.54 \\
8.87 \\
8.26 \\
8.96 \\
9.09\end{array}$ & 0.75 \\
\hline $\begin{array}{l}\text { Lint cotton } \\
\text { yield }(k / f)\end{array}$ & $\begin{array}{c}\text { Giza 70 } \\
\text { Giza 87 } \\
\text { Giza 88 } \\
\text { Giza 92 } \\
(\text { G.77 × S6) } \\
\text { [G.84 (G.70 X G 51b)] × Pima } 62 \\
\text { G.88 }(\text { G.68 } \times \text { G.45) }\end{array}$ & $\begin{array}{c}9.66 \\
8.42 \\
9.81 \\
10.13 \\
8.24 \\
10.66 \\
10.81\end{array}$ & $\begin{array}{c}7.03 \\
7.52 \\
8.45 \\
9.90 \\
7.20 \\
10.27 \\
9.52\end{array}$ & $\begin{array}{c}9.70 \\
9.39 \\
9.83 \\
11.07 \\
8.40 \\
13.27 \\
11.83\end{array}$ & $\begin{array}{c}7.54 \\
8.28 \\
8.37 \\
9.45 \\
7.25 \\
10.77 \\
10.16\end{array}$ & $\begin{array}{c}8.06 \\
7.54 \\
8.85 \\
10.12 \\
9.06 \\
10.95 \\
10.58\end{array}$ & 0.92 \\
\hline $\begin{array}{l}\text { Boll weight } \\
\text { (g) }\end{array}$ & $\begin{array}{c}\text { Giza 70 } \\
\text { Giza 87 } \\
\text { Giza 88 } \\
\text { Giza 92 } \\
(\text { G.77 × S6) } \\
\text { [G.84 (G.70 X G 51b)] × Pima } 62 \\
\text { G.88 }(\text { G.68 } \times \text { G.45 })\end{array}$ & $\begin{array}{l}2.78 \\
2.45 \\
2.79 \\
2.70 \\
2.45 \\
2.78 \\
2.83\end{array}$ & $\begin{array}{l}2.46 \\
2.31 \\
2.58 \\
2.73 \\
2.35 \\
2.86 \\
2.80\end{array}$ & $\begin{array}{l}2.62 \\
2.44 \\
2.90 \\
2.75 \\
2.45 \\
2.86 \\
2.85\end{array}$ & $\begin{array}{l}2.26 \\
2.16 \\
2.25 \\
2.36 \\
2.02 \\
2.46 \\
2.50\end{array}$ & $\begin{array}{l}2.62 \\
2.49 \\
2.54 \\
2.65 \\
2.65 \\
2.92 \\
2.77\end{array}$ & 0.15 \\
\hline $\begin{array}{c}\text { Lint } \\
\text { percentage }\end{array}$ & $\begin{array}{c}\text { Giza 70 } \\
\text { Giza 87 } \\
\text { Giza 88 } \\
\text { Giza 92 } \\
(\text { G.77 × S6) } \\
\text { [G.84 (G.70 X G 51b) } \times \text { Pima } 62 \\
\text { G.88 }(\text { G.68 } \times \text { G.45 })\end{array}$ & $\begin{array}{l}38.41 \\
34.28 \\
37.76 \\
37.56 \\
35.51 \\
40.04 \\
38.41\end{array}$ & $\begin{array}{l}37.28 \\
34.38 \\
37.81 \\
37.66 \\
35.85 \\
39.56 \\
37.45\end{array}$ & $\begin{array}{l}38.45 \\
33.71 \\
38.22 \\
36.90 \\
36.01 \\
40.85 \\
37.76\end{array}$ & $\begin{array}{l}37.69 \\
33.38 \\
37.02 \\
35.75 \\
35.09 \\
38.04 \\
37.26\end{array}$ & $\begin{array}{l}37.41 \\
33.62 \\
37.50 \\
36.25 \\
35.24 \\
38.98 \\
36.91\end{array}$ & 0.85 \\
\hline $\begin{array}{l}\text { Seed index } \\
\text { (g) }\end{array}$ & $\begin{array}{c}\text { Giza 70 } \\
\text { Giza 87 } \\
\text { Giza 88 } \\
\text { Giza 92 } \\
(\text { G.77 × S6) } \\
{[\text { G.84 (G.70 X G 51b)] × Pima } 62} \\
\text { G.88 }(\text { G.68 } \times \text { G.45 })\end{array}$ & $\begin{array}{l}9.54 \\
9.60 \\
9.77 \\
9.83 \\
9.17 \\
9.58 \\
9.95\end{array}$ & $\begin{array}{l}8.38 \\
8.96 \\
9.04 \\
9.04 \\
8.84 \\
9.63 \\
9.53\end{array}$ & $\begin{array}{c}9.21 \\
9.25 \\
9.86 \\
9.70 \\
9.64 \\
9.44 \\
10.19\end{array}$ & $\begin{array}{l}8.10 \\
8.08 \\
8.49 \\
8.75 \\
7.96 \\
8.61 \\
8.84\end{array}$ & $\begin{array}{c}9.37 \\
9.22 \\
9.86 \\
10.04 \\
9.81 \\
10.10 \\
10.05\end{array}$ & NS \\
\hline Lint index (g) & $\begin{array}{c}\text { Giza 70 } \\
\text { Giza 87 } \\
\text { Giza 88 } \\
\text { Giza 92 } \\
(\text { G.77 × S6) } \\
\text { [G.84 (G.70 X G 51b)] × Pima } 62 \\
\text { G.88 }(\text { G.68 } \times \text { G.45 })\end{array}$ & $\begin{array}{l}5.95 \\
5.01 \\
5.93 \\
5.92 \\
5.05 \\
6.40 \\
6.21\end{array}$ & $\begin{array}{l}4.99 \\
4.69 \\
5.48 \\
5.44 \\
4.93 \\
6.31 \\
5.71\end{array}$ & $\begin{array}{l}5.76 \\
4.70 \\
6.10 \\
5.67 \\
5.42 \\
6.51 \\
6.18\end{array}$ & $\begin{array}{l}4.90 \\
4.05 \\
5.02 \\
4.88 \\
4.30 \\
5.28 \\
5.28\end{array}$ & $\begin{array}{l}5.54 \\
4.65 \\
5.88 \\
5.70 \\
5.31 \\
6.43 \\
5.87\end{array}$ & NS \\
\hline $\begin{array}{l}\text { Upper half } \\
\text { mean }(\mathrm{mm})\end{array}$ & $\begin{array}{c}\text { Giza 70 } \\
\text { Giza 87 } \\
\text { Giza 88 } \\
\text { Giza 92 } \\
(\text { G.77 × S6) } \\
\text { [G.84 (G.70 X G 51b)] × Pima } 62 \\
\text { G.88 }(\text { G.68 } \times \text { G.45 })\end{array}$ & $\begin{array}{l}35.26 \\
35.02 \\
35.72 \\
34.15 \\
36.92 \\
36.05 \\
36.41\end{array}$ & $\begin{array}{l}35.10 \\
34.60 \\
35.90 \\
32.28 \\
36.70 \\
34.34 \\
33.62\end{array}$ & $\begin{array}{l}34.92 \\
35.68 \\
35.89 \\
33.20 \\
36.75 \\
36.41 \\
36.00\end{array}$ & $\begin{array}{l}33.41 \\
34.34 \\
34.26 \\
32.95 \\
35.65 \\
35.15 \\
34.51\end{array}$ & $\begin{array}{l}33.71 \\
35.61 \\
35.31 \\
33.34 \\
35.65 \\
34.55 \\
34.76\end{array}$ & 0.07 \\
\hline $\begin{array}{l}\text { Fiber } \\
\text { strength } \\
\text { (g/tex) }\end{array}$ & $\begin{array}{c}\text { Giza 70 } \\
\text { Giza 87 } \\
\text { Giza 88 } \\
\text { Giza 92 } \\
(\text { G.77 × S6) } \\
\text { [G.84 (G.70 X G 51b)] × Pima } 62 \\
\text { G.88 }(\text { G.68 } \times \text { G.45) }\end{array}$ & $\begin{array}{l}45.20 \\
43.94 \\
47.81 \\
45.50 \\
48.20 \\
47.65 \\
47.05\end{array}$ & $\begin{array}{l}45.50 \\
44.56 \\
50.70 \\
46.14 \\
46.02 \\
43.14 \\
44.60\end{array}$ & $\begin{array}{l}44.48 \\
43.46 \\
49.75 \\
46.29 \\
47.21 \\
48.66 \\
45.68\end{array}$ & $\begin{array}{l}45.98 \\
46.44 \\
46.12 \\
49.14 \\
43.76 \\
46.48 \\
43.95 \\
\end{array}$ & $\begin{array}{l}41.42 \\
45.44 \\
47.62 \\
46.84 \\
46.00 \\
41.61 \\
44.50\end{array}$ & 0.07 \\
\hline $\begin{array}{l}\text { Micronaire } \\
\text { reading }\end{array}$ & $\begin{array}{c}\text { Giza 70 } \\
\text { Giza 87 } \\
\text { Giza 88 } \\
\text { Giza 92 } \\
(\text { G.77 × S6) } \\
\text { [G.84 (G.70 X G 51b)] × Pima } 62 \\
\text { G.88 }(\text { G.68 } \times \text { G.45) }\end{array}$ & $\begin{array}{l}3.84 \\
3.22 \\
3.71 \\
3.50 \\
3.04 \\
3.81 \\
3.62\end{array}$ & $\begin{array}{l}3.56 \\
3.09 \\
3.65 \\
3.50 \\
2.85 \\
3.65 \\
3.38\end{array}$ & $\begin{array}{l}3.76 \\
3.18 \\
3.80 \\
3.51 \\
2.90 \\
3.60 \\
3.69\end{array}$ & $\begin{array}{l}3.28 \\
2.91 \\
2.99 \\
2.92 \\
2.61 \\
3.30 \\
3.05\end{array}$ & $\begin{array}{l}3.58 \\
3.20 \\
3.52 \\
3.91 \\
3.08 \\
3.88 \\
3.56\end{array}$ & 0.06 \\
\hline
\end{tabular}

Note: NS= non significant 
Table. 7. Effect of the interaction between genotypes and growing seasons on the studied traits.

\begin{tabular}{|c|c|c|c|c|}
\hline Characters & Genotypes & 2009 & 2010 & LSD 0.05 \\
\hline $\begin{array}{l}\text { Seed cotton } \\
\text { yield }(\mathrm{k} / \mathrm{f})\end{array}$ & $\begin{array}{c}\text { Giza 70 } \\
\text { Giza 87 } \\
\text { Giza 88 } \\
\text { Giza } 92 \\
(\text { G.77 } \times \text { S6) } \\
{[\text { G.84 (G.70 } \times \quad \text { G 51b) }] \times \text { Pima } 62} \\
\text { G.88 }(\text { G.68 } \times \text { G.45 })\end{array}$ & $\begin{array}{l}6.76 \\
7.77 \\
7.05 \\
8.61 \\
6.67 \\
9.04 \\
8.75\end{array}$ & $\begin{array}{l}7.35 \\
7.70 \\
8.24 \\
8.89 \\
7.72 \\
8.94 \\
9.12\end{array}$ & 0.47 \\
\hline $\begin{array}{l}\text { Lint cotton yield } \\
\qquad(\mathrm{k} / \mathrm{f})\end{array}$ & $\begin{array}{c}\text { Giza 70 } \\
\text { Giza 87 } \\
\text { Giza 88 } \\
\text { Giza 92 } \\
(\text { G.77 × S6) } \\
\text { [G.84 (G.70 X G 51b)] × Pima } 62 \\
\text { G.88 }(\text { G.68 } \times \text { G.45) }\end{array}$ & $\begin{array}{r}8.20 \\
8.32 \\
8.36 \\
9.95 \\
7.47 \\
11.31 \\
10.31\end{array}$ & $\begin{array}{c}8.60 \\
8.14 \\
9.76 \\
10.32 \\
8.59 \\
11.06 \\
10.86\end{array}$ & 0.58 \\
\hline Boll weight (g) & $\begin{array}{c}\text { Giza 70 } \\
\text { Giza } 87 \\
\text { Giza } 88 \\
\text { Giza } 92 \\
(\text { G.77 } \times \text { S6) } \\
{[\text { G.84 (G.70 X G 51b) }] \times \text { Pima } 62} \\
\text { G.88 }(\text { G.68 } \times \text { G.45 })\end{array}$ & $\begin{array}{l}2.46 \\
2.35 \\
2.59 \\
2.61 \\
2.40 \\
2.72 \\
2.63\end{array}$ & $\begin{array}{l}2.64 \\
2.39 \\
2.63 \\
2.66 \\
2.37 \\
2.83 \\
2.86\end{array}$ & 0.10 \\
\hline Lint percentage & $\begin{array}{c}\text { Giza 70 } \\
\text { Giza 87 } \\
\text { Giza 88 } \\
\text { Giza 92 } \\
(\text { G.77 × S6) } \\
{[\text { G.84 (G.70 X G 51b) }] \times \text { Pima } 62} \\
\text { G.88 }(\text { G.68 } \times \text { G.45) }\end{array}$ & $\begin{array}{l}38.50 \\
34.15 \\
37.70 \\
36.77 \\
35.58 \\
39.66 \\
37.34\end{array}$ & $\begin{array}{l}37.20 \\
33.60 \\
37.62 \\
36.88 \\
35.50 \\
39.33 \\
37.78\end{array}$ & 0.54 \\
\hline Seed index ( $\mathrm{g}$ ) & $\begin{array}{c}\text { Giza 70 } \\
\text { Giza } 87 \\
\text { Giza } 88 \\
\text { Giza } 92 \\
(\text { G.77 } \times \text { S6) } \\
{[\text { G.84 (G.70 X G 51b) }] \times \text { Pima } 62} \\
\text { G.88 }(\text { G.68 } \times \text { G.45 }) \\
\end{array}$ & $\begin{array}{l}8.62 \\
8.99 \\
9.14 \\
9.38 \\
8.91 \\
9.38 \\
9.31\end{array}$ & $\begin{array}{c}9.22 \\
9.05 \\
9.66 \\
9.56 \\
9.26 \\
9.57 \\
10.11 \\
\end{array}$ & NS \\
\hline Lint index (g) & $\begin{array}{c}\text { Giza 70 } \\
\text { Giza 87 } \\
\text { Giza } 88 \\
\text { Giza } 92 \\
(\text { G.77 × S6) } \\
{[\text { G.84 (G.70 X G 51b) }] \times \text { Pima } 62} \\
\text { G.88 }(\text { G.68 } \times \text { G.45) }\end{array}$ & $\begin{array}{l}5.40 \\
4.67 \\
5.54 \\
5.47 \\
4.93 \\
6.18 \\
5.56\end{array}$ & $\begin{array}{l}5.45 \\
4.57 \\
5.82 \\
5.57 \\
5.08 \\
6.19 \\
6.13\end{array}$ & 0.23 \\
\hline $\begin{array}{l}\text { Upper half mean } \\
(\mathrm{mm})\end{array}$ & $\begin{array}{c}\text { Giza 70 } \\
\text { Giza 87 } \\
\text { Giza } 88 \\
\text { Giza } 92 \\
(\text { G.77 × S6) } \\
{[\text { G.84 (G.70 X G 51b) }] \times \text { Pima } 62} \\
\text { G.88 }(\text { G.68 } \times \text { G.45 })\end{array}$ & $\begin{array}{l}33.83 \\
34.52 \\
35.54 \\
32.98 \\
35.98 \\
34.90 \\
34.94\end{array}$ & $\begin{array}{l}35.14 \\
35.58 \\
35.29 \\
33.39 \\
36.70 \\
35.70 \\
35.18\end{array}$ & 0.04 \\
\hline $\begin{array}{l}\text { Fiber strength } \\
\text { (g/tex) }\end{array}$ & $\begin{array}{c}\text { Giza 70 } \\
\text { Giza 87 } \\
\text { Giza } 88 \\
\text { Giza } 92 \\
(\text { G.77 × S6) } \\
{[\text { G.84 (G.70 X G 51b) }] \times \text { Pima } 62} \\
\text { G.88 }(\text { G.68 } \times \text { G.45) }\end{array}$ & $\begin{array}{l}43.05 \\
44.38 \\
47.76 \\
47.22 \\
46.60 \\
45.92 \\
45.90\end{array}$ & $\begin{array}{l}45.98 \\
45.16 \\
49.05 \\
46.34 \\
45.88 \\
45.10 \\
44.42\end{array}$ & 0.04 \\
\hline $\begin{array}{l}\text { Micronaire } \\
\text { reading }\end{array}$ & $\begin{array}{c}\text { Giza 70 } \\
\text { Giza 87 } \\
\text { Giza 88 } \\
\text { Giza 92 } \\
(\text { G.77 × S6) } \\
{[\text { G.84 (G.70 X G 51b) }] \times \text { Pima } 62} \\
\text { G.88 }(\text { G.68 } \times \text { G.45) }\end{array}$ & $\begin{array}{l}3.50 \\
3.16 \\
3.38 \\
3.51 \\
2.80 \\
3.64 \\
3.26\end{array}$ & $\begin{array}{l}3.70 \\
3.08 \\
3.70 \\
3.43 \\
2.87 \\
3.65 \\
3.66\end{array}$ & 0.04 \\
\hline
\end{tabular}

Note: NS= non significant 
The promising strain G.88 (G.68 × G.45) gave the highest values for boll weight and seed index in the second season (2010). But the promising strain [G.84 (G.70 X G 51b)] $\times$ Pima 62 gave the highest value for lint percentage in the first season, the same promising strain gave the highest value for lint index in two seasons.

With respect to the fiber properties, it can be seen that fiber length (upper half mean $\mathrm{mm}$ ) ranged from $32.98 \mathrm{~mm}$ for Giza 92 during the first season to $36.70 \mathrm{~mm}$ for the promising strain (Giza $77 \times \mathrm{S} 6)$ during the second season. Fiber strength $(\mathrm{g} / \mathrm{tex})$ ranged from 43.05 for the commercial cultivar Giza 70 during the first season to 49.05 for Giza 88 during the second season. The promising strain (Giza $77 \times$ S6) gave the best fineness (micronaire reading) during the two seasons. The data indicated that genotypes under study reacted differently in different seasons. These results are in accordance with those obtained by Abo El-Zahab et. al. (1992), Badr (1994), AbouTour et. al. (1996), Badr and El-Sayed (2004), Hassan et. al. (2005), Arafa et. al. (2008) and El-Feky and Hassan (2011), they found that the interaction between genotypes and seasons was significantly affected for yield traits and fiber properties.

\section{Effect of the interaction between cotton genotypes, growing location and growing seasons on cotton yield, yield components and lint quality}

Data reported in Table (1) showed that the second order interaction of genotypes $\mathrm{x}$ locations $\mathrm{x}$ seasons were significant for all traits except, seed index) indicating that the cotton genotypes under study responded differently under different environments for these traits. The results obtained might also suggest that this differential varietals response might be due to location effects rather than year. These results were in agreement with those obtained by Abdel-Salam et. al. (1985), Abo ElZahab et. al. (1992), Badr (1994), Abou-Tour et. al. (1996), Badr and El-Sayed (2004), Hassan et. al. (2005), Hassan (2006) and Arafa et. al. (2008), who reported that such effect was significant for some yield, yield components and fiber properties.

From the above results, it is recommended that the promising strain (Giza $77 \times$ S6) may be grown in El-Beheira region to replace Giza 87 since it exceeded it significantly in the most yield components and fiber properties. Also, the promising strains [G.84 (G.70 X G 51b)] × Pima S62 and G.88 (G.68 × G.45) as an expected substitution for the commercial cultivars Giza 70 and Giza 88. It is evident the two promising strains produced the highest values for the most yield, yield components and fiber properties at El-Dakahlia region, these promising strains may be recommended to be grown at El-Dakahlia governorate. However, further to continue evaluating cotton genotypes, old or newly produced, by growing them at several locations over an adequate number of years before recommending any variety for a certain location. 


\section{REFERENCES}

1. Abdel - Salam, M. S, M. M. Seyam and F. M. El - Rays. 1985. Quality evaluation of some newly introduced promising cotton hybrids. Agric. Res. Rev., 63(6): 121 $-137$.

2. Abo El - Zahab, A. A., F. F. Soad, M. A. El - Kilany and A. A. El - Ghani. 1992. Cultivar $x$ environment interaction in Egyptian cotton. 1 - Seed cotton yield and its components. Proc. 5th Conf. Agron. Zagazig, vol. 2: $775-788$.

3. Abou Tour, H. B., S. M. A. Seyam and L. M. A. Abd El - Rahman. 1996. Analytical study on the economic characters of new and commercial Egyptian cotton varieties. J. Agric. Res., 74(3): 781 - 791.

4. Arafa S. Abeer, O.D.M. Nour and I.S.M. Hassan. 2008. Impact of accumulated heat units (DD15's) on the performance of some Egyptian cotton cultivars. J. Agric. Res., 86 (5): 1945 - 1956.

5. A.S.T.M. 1986. American society for testing materials, D-4605. U.S.A.

6. Badr, S. S. M. 1994. Studies on lint, yarn and seed qualities of cotton as affected by different locations in Egypt. Ph. D. Thesis, Fac. Of Agric. (Saba Basha), Alex. Univ.

7. Badr, S. S. M. 2003. Comparative evaluation of promising hybrid Giza 84 (Giza 74 $\times$ Giza 68) and Extra long staple cotton varieties grown in North Delta. Egypt J. Agric. Res., 81(3): 1149-1169.

8. Badr, S. S. M. and S.A. El-Sayed. 2004. Evaluation of some long staple Egyptian cotton genotypes for yield, seed quality and viability characters. J. Agric. Res. Tanta Univ. 30(2): $304-326$.

9. El-Feky, H.H. and S.A. Hassan. 2011. Effect of cultivar and growing location on ginning efficiency and cotton quality. Egypt. J. Agric. Res., 89(2): 567-578.

10. Hanuman, S., and S. Singh. 1994. Phenotypic stability for some quality traits in American cotton. Annals of Biology. Ludhiana. 10, 1:120-124.

11. Hassan, I.S.M. 2000. Evaluation of two new extra long staple cotton genotypes and three commercial cultivars grown at North Delta. Annals of Agric. Sci., Moshtohor, Vol. 38(4): 1839-1846.

12. Hassan, I. S. M., Amal S. Mohamed and Laila M. A. Abdel - Rahman. 2005. Comparative study on seed cotton yield, oil and protein contents in the seed of some Egyptian cotton cultivars grown at different locations. J. Agric. Res, 82(2): $735-750$. 
13. Hassan, I.S.M. 2006. Comparative evaluation of two promising hybrids of cotton and three long staple commercial cultivars grown at South and middle Delta. Egypt. J. of Appl. Sci., 21(7): 128-142.

14. Hassan, I.S.M., H.B. Abou-Tour and S.S. Badr. 2006. Evaluation of two new extra long staple cotton varieties with commercial cultivars grown in North Delta. Egypt. J. Agric. Res., 84(5): 1561-1576.

15. Mcintosh, M.S. 1983. Analysis of combined experiments. Agron. J., 75: 153 155.

16. Senedcor, G. W. and W. G. Cochran. 1982. Statistical methods applied to experiments in Agriculture and biology. 7th ed. seventh reprinting. The Iowa State Univ. Press, Ames., Iowa, U. S. A.

17. Seyam, S.M. and L.M.A. Abdel Rahman. 1994. Evaluating the differential potential yield of existing commercial cotton varieties in their growing locations. J. Appl. Sci., 9(10): 223-234. 


\title{
تقييم ثلاث سلالات مبشرة من الاقطان قائقة الطول
}

\author{
إبراهيم سيد محمد حسن حاتم أحمد إدريس سامي سعد محمد بدر \\ معة بحوث القطن - مركز البحوث الزراعية - الجيزة
}

تمت مقارنة ثلاثة هجن مبشرة من أصناف القطن فائقة الطول مع أربعة أصناف تجارية منزرعة في

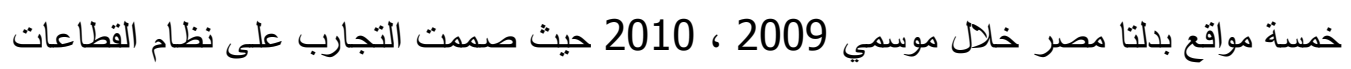
الكاملة العشوائية ذات أربع مكررات وقد اختبرت صفات محصول القطن الزهر والثعر (قنطار /فدان) ،

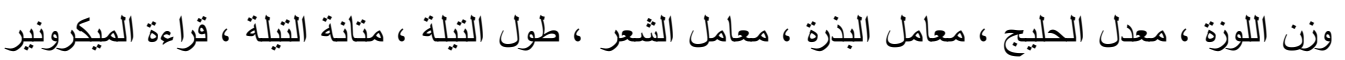

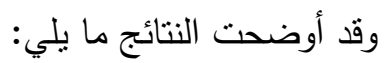
• كان تأثثر كل من التراكيب الوراثيـة والمنـاطق والسنوات والتفاعل بين المنـاطق والسنوات عـالي المعنوية لصفات المحصول ومكوناته وصفات جودة التيلة.

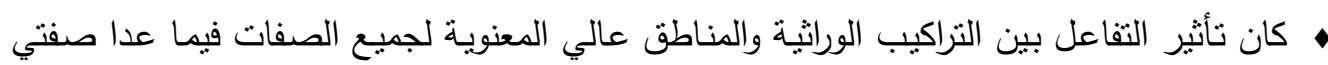

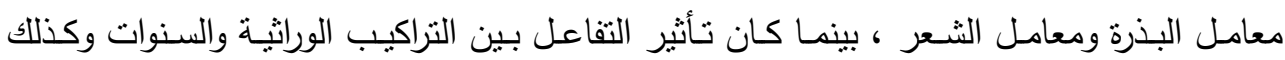
التفاعل من الدرجة الثانية معنويا لجميع الصفات فيما عدا صفة معامل البذرة.

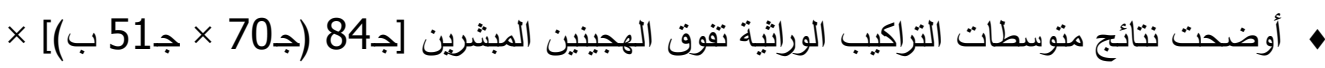
بيما 62 ، ج88 ( جـ88 × جـ45) في معظم صفات المحصول ومكوناته. بينما تفوق الهجين المبشر (ج77 × س6) في صفتي طول التيلة والنعومة على جميع التراكيب الوراثية الأخرى. • كذلك أوضحت النتائج تفوق الهجين المبشر (ج) × نعومـة التيلة في محافظات كفر الشيخ والدقهلية ودمياط ولكن لوحظ أن محافظة البحيرة ملائمـة لزراعة هذا الهجين حيث تفوق في معظم الصفات تحت الدراسة.

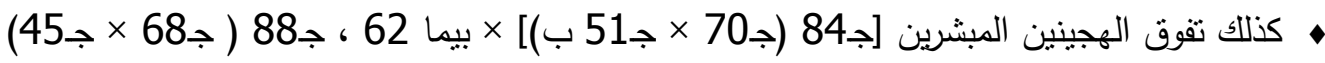
على الصنفين التجاريين ج70 ، ج88 في معظم صفات المحصول ومكوناته وصفات جودة التيلة في محافظة الدقهلية. • أوضحت النتائج المتحصل عليها أهمية الدور الذي يلعبه كل من التركيب الوراثي والظروف البيئية وكذلك التفاعل بينهما في صفات المحصول وجودة التيلة مما يدل على انه من الضروري استمرار الثقييم لهذه التراكيب الوراثية في جهات متعددة ولعدة سنوات. 